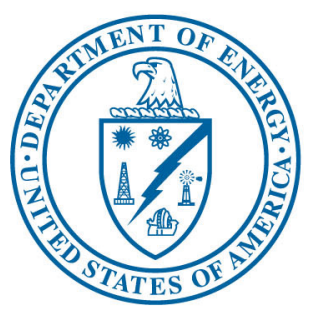

U.S. Department of Energy

Idaho Operations Office

INL Site FY 2010 Executable Plan for Energy and Transportation Fuels Management with the FY 2009 Annual Report

December 2009 
DOE/ID-11383

Rev. 1

\section{INL Site FY 2010 Executable Plan for Energy and Transportation Fuels Management with the FY 2009 Annual Report}

December 2009

Prepared for the 
(This Page Intentionally Left Blank) 
(This Page Intentionally Left Blank) 


\begin{tabular}{|c|c|c|c|c|}
\hline$(i)$ & \multicolumn{4}{|c|}{$\begin{array}{c}\text { DOE ORDER 430.2B INL SITE EXECUTABLE PLAN } \\
\text { TEAM GOAL SUMMARY }\end{array}$} \\
\hline Goal Elements & $\begin{array}{c}\text { Plan Meets } \\
\text { Goal }\end{array}$ & $\begin{array}{c}\text { Plan } \\
\text { Exceeds } \\
\text { Goal }\end{array}$ & $\begin{array}{c}\text { Plan Falls } \\
\text { Short of } \\
\text { Goal }\end{array}$ & Comments \\
\hline Energy Efficiency & $\sqrt{\nabla}$ & $\sqsubset$ & $\sqsubset$ & $\begin{array}{l}\text { This version of the Executable Plan provides } \\
\text { a high level analysis on strategies to meet } \\
\text { the energy efficiency goals for the INL Site. } \\
\text { Since the ESPC or UESC projects have not } \\
\text { been fully developed or constructed by the } \\
\text { Energy Services Companies or Utilities, and } \\
\text { since new process facilities may consume } \\
\text { significant energy to perform their functions, } \\
\text { more detailed evaluations in the next year or } \\
\text { two may reveal areas where the INL Site } \\
\text { may exceed or fall short of the energy } \\
\text { efficiency goals. This Plan will be updated } \\
\text { annually to reflect new opportunities and } \\
\text { issues as they are identified. }\end{array}$ \\
\hline Renewable Energy & $\sqrt{\nabla}$ & ᄃ & $\sqsubset$ & $\begin{array}{l}\text { This version of the Executable Plan provides } \\
\text { a high level analysis on strategies to meet } \\
\text { the Renewable Energy goals for the INL Site. } \\
\text { Based upon the analysis conducted with } \\
\text { NREL, several renewable energy projects are } \\
\text { being pursued. However, plans to purchase } \\
\text { RECs at the minimum required amounts are } \\
\text { in place. This Plan will be updated annually } \\
\text { to reflect new opportunities and issues as } \\
\text { they are developed. }\end{array}$ \\
\hline Water & $\nabla$ & ᄃ & ᄃ & $\begin{array}{l}\text { This version of the Executable Plan provides } \\
\text { a high level analysis on strategies to meet } \\
\text { the Water Reduction goals for the INL Site. } \\
\text { As water use intensity is heavily influenced } \\
\text { by square footage reductions accomplished } \\
\text { through increased ARRA funded D\&D work, } \\
\text { the INL Site may fall short of the Water } \\
\text { Reduction goals. This Plan will be updated } \\
\text { annually to reflect new opportunities and } \\
\text { issues as they are identified. }\end{array}$ \\
\hline
\end{tabular}




\begin{tabular}{|c|c|c|c|c|}
\hline (1) & \multicolumn{4}{|c|}{$\begin{array}{c}\text { DOE ORDER 430.2B INL SITE EXECUTABLE PLAN } \\
\text { TEAM GOAL SUMMARY }\end{array}$} \\
\hline Goal Elements & $\begin{array}{c}\text { Plan Meets } \\
\text { Goal }\end{array}$ & $\begin{array}{c}\text { Plan } \\
\text { Exceeds } \\
\text { Goal }\end{array}$ & $\begin{array}{c}\text { Plan Falls } \\
\text { Short of } \\
\text { Goal } \\
\end{array}$ & Comments \\
\hline $\begin{array}{l}\text { Transportation } \\
\text { Fuels Management }\end{array}$ & $\sqrt{\nabla}$ & Г & ᄃ & $\begin{array}{l}\text { This version of the Executable Plan provides } \\
\text { a high level analysis on strategies to meet } \\
\text { the transportation and fleet management } \\
\text { goals for the INL Site. The strategies } \\
\text { outlined depend on the availability of } \\
\text { alternative fuels at cost competitive prices in } \\
\text { the Idaho Falls area, on either ESPCS or DOE } \\
\text { funding to upgrade site fueling stations, and } \\
\text { on the ability to obtain buses for the INL Site } \\
\text { bus fleet that are able to use alternative fuel } \\
\text { (CNG). This Plan will be updated annually to } \\
\text { reflect new opportunities and issues as they } \\
\text { are identified. }\end{array}$ \\
\hline $\begin{array}{l}\text { High Performance } \\
\text { and Sustainable } \\
\text { Buildings }\end{array}$ & $\sqrt{\nabla}$ & $\sqsubset$ & $\sqsubset$ & $\begin{array}{l}\text { This version of the Executable Plan provides } \\
\text { a high level analysis on strategies to meet } \\
\text { the High Performance and Sustainable } \\
\text { Buildings goals for the INL Site. The INL site } \\
\text { has prioritized existing buildings for } \\
\text { consideration of upgrades to incorporate the } \\
\text { Guiding Principles through ESPC or UESC as } \\
\text { well as through normal DOE funded } \\
\text { maintenance projects. Since those projects } \\
\text { and contracts have not yet been designed or } \\
\text { negotiated, the results cannot be accurately } \\
\text { projected. This Plan will be updated annually } \\
\text { to reflect more detailed information and } \\
\text { projections. }\end{array}$ \\
\hline
\end{tabular}




\title{
INL Site FY 2010 Executable Plan for Energy and Transportation Fuels Management with the FY 2009 Annual Report
}

\author{
DOE/ID-11383
}

Revision 1

December 2009

Approved By:

Dennis M. Miotla

Date

Interim Manager

DOE Idaho Operations Office 
(This Page Intentionally Left Blank) 


\section{INL Site FY 2010 Executable Plan for Energy and Transportation Fuels Management with the FY 2009 Annual Report}

DOE/ID-11383

Revision 1

December 2009

Approved By:

Richard B. Provencher

Idaho Cleanup Project 
(This Page Intentionally Left Blank) 


\section{INL Site FY 2010 Executable Plan for Energy and Transportation Fuels Management with the FY 2009 Annual Report}

DOE/ID-11383

Revision 1

December 2009

Approved By:

John J. Grossenbacher

Date

Director, Idaho National Laboratory and

President, Battelle Energy Alliance, LLC 
(This Page Intentionally Left Blank) 


\section{INL Site FY 2010 Executable Plan for Energy and Transportation Fuels Management with the FY 2009 Annual Report}

DOE/ID-11383

Revision 1

December 2009

Approved By:

John C. Fulton, President

Date

Idaho Cleanup Project

CH2M-WG Idaho, LLC 
(This Page Intentionally Left Blank) 


\title{
INL Site FY 2010 Executable Plan for Energy and Transportation Fuels Management with the FY 2009 Annual Report
}

\author{
DOE/ID-11383 \\ Revision 1
}

December 2009

\begin{abstract}
Approved By:
\end{abstract}
Jeffrey D. Mousseau

Date

President and General Manager

Bechtel BWXT Idaho, LLC

Advanced Mixed Waste Treatment Project 
(This Page Intentionally Left Blank) 


\section{CONTENTS}

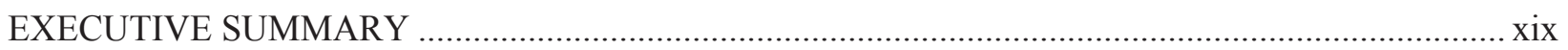

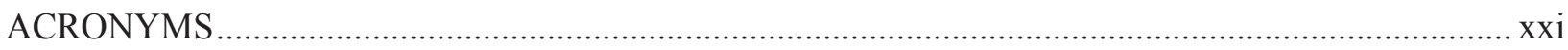

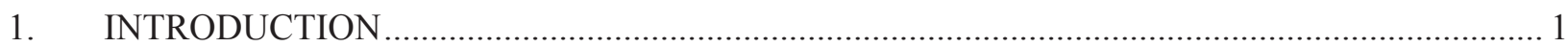

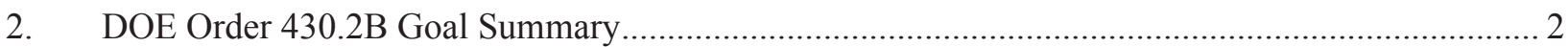

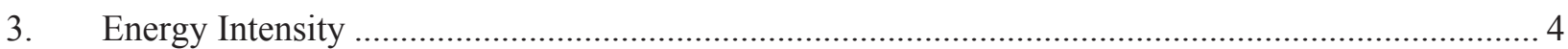

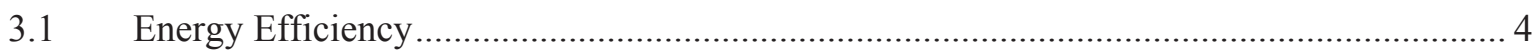

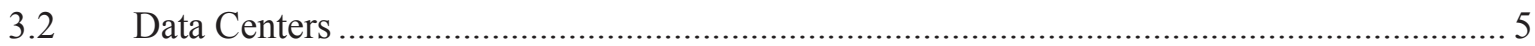

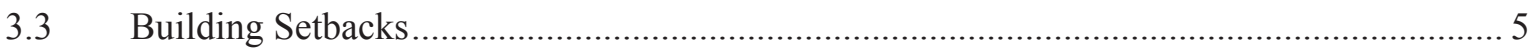

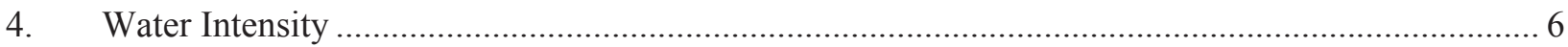

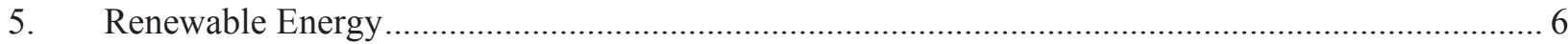

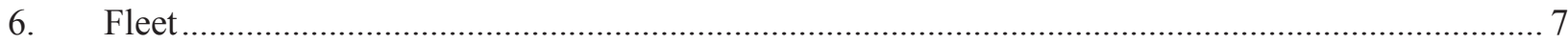

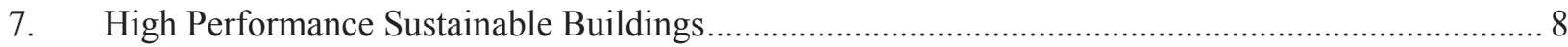

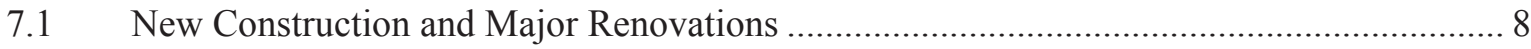

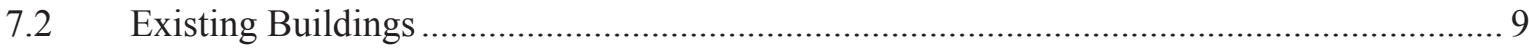

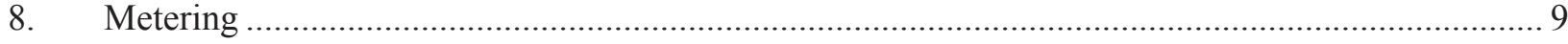

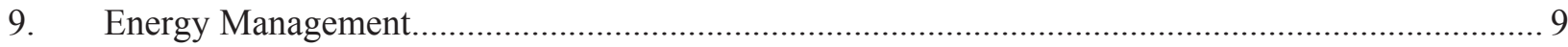

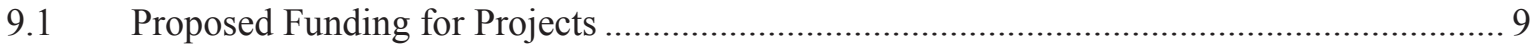

9.2 Additional DOE O 430.2B Elements to Address ......................................................... 10

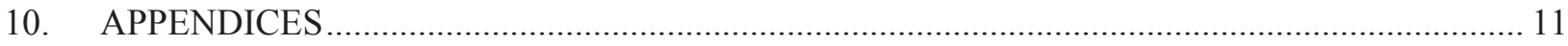

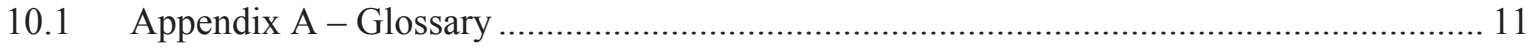

10.2 Appendix B - Consolidated Energy Data Report (CEDR) ......................................... 13

Note: The FY 2009 Consolidated Energy Data Report is attached as a hard copy and/or Excel file (FY2009 Consolidated Energy Data Report.xls)............................................................ 13 
(This Page Intentionally Left Blank) 


\section{EXECUTIVE SUMMARY}

It is the policy of the Department of Energy (DOE) that sustainable energy and transportation fuels management will be integrated into DOE operations to meet obligations under Executive Order (EO) 13423 "Strengthening Federal Environmental, Energy, and Transportation Management", the Instructions for Implementation of EO 13423, as well as Guidance Documents issued in accordance thereto and any modifications or amendments that may be issued from time to time. In furtherance of this obligation, DOE established strategic performancebased energy and transportation fuels goals and strategies through the Transformational Energy Action Management (TEAM) Initiative, which were incorporated into DOE Order 430.2B "Departmental Energy, Renewable Energy, and Transportation Management" and were also identified in DOE Order 450.1A, "Environmental Protection Program". These goals and accompanying strategies are to be implemented by DOE sites through the integration of energy and transportation fuels management into site Environmental Management Systems (EMS).

This document presents the INL Site FY 2010 Executable Plan for Energy and Transportation Fuels Management pursuant to DOE Orders 430.2B and 450.1A for FY 2010. The Plan was prepared in accordance with the DOE "Guidance for Developing the Executable Plan". The Plan also provides Annul Report data and information on energy and fuels usage for FY 2009. The Annual Report data for FY 2009 are provided on the Consolidated Energy Data Report (CEDR) in Appendix B.

The work at the INL Site is currently managed through three major contracts, each with a very different work scope and contract type. The Idaho National Laboratory contract is funded through the Office of Nuclear Energy (NE) and others including the National Nuclear Security Administration (NNSA), Office of Energy Efficiency (EE), and Work for Others (WFO) and encompasses the Site bus fleet, the electric power distribution system to each of the facility areas, and includes operation of the Advanced Test Reactor (ATR) Complex, Manufacturing and Fuels Complex (MFC), Central Facilities Area (CFA), Critical Infrastructure Test Research Complex (CITRC), Specific Manufacturing Complex (SMC), and the Research and Education Complex (REC). In addition, any renewable energy generation projects would likely fall within the scope of the INL contract. The INL contractor has been the point of consolidation for INL Site energy management reporting.

The Office of Environmental Management (EM) funded projects at the INL Site are the Idaho Cleanup Project (ICP) and the Advanced Mixed Waste Treatment Project (AMWTP). The ICP is responsible for the remainder of the EM funded cleanup and closure work at the INL Site. The AMWTP scope is to retrieve, repackage, treat, and ship certain transuranic (TRU) waste stored at the INL Site, primarily the TRU waste stored on above ground pads at the Radioactive Waste Management Complex (RWMC). Due to the nature of the work, neither of these projects or contracts are intended to expand in scope or build significant new buildings or processes except as required to complete the cleanup of legacy waste and Decontamination and Decommissioning (D\&D) of obsolete processes and facilities. They have minimal infrastructure obligations outside of their defined facility areas, so their obligations in the Plan are limited to operation, maintenance, construction, and renovation of buildings and processes within their area of control and of fleet transportation within their direct control.

Due to the nature of these various INL Site missions, many of the related operations can be cyclical and result in varying usages of energy and water. As facilities are removed or processes are modified, the INL Site energy and water usage intensities (use per square foot) can vary seemingly unrelated to actual overall resource reduction efforts. Where appropriate, this Plan identifies and discusses these variances.

The purpose of this Plan is to meet the requirements of the Energy Policy Act of 2005 (EPAct 2005), and the DOE Orders 430.2B and 450.1A by increasing the sustainability of INL Site operations and reducing or eliminating energy waste without compromising the overall missions of the INL Site. The success of the Plan is dependent on financial and management support. The signatures on previous pages indicate DOE Idaho Operations Office (DOE-ID), INL, ICP, and AMWTP contractor management commitment to this Plan. 
(This Page Intentionally Left Blank) 


\section{ACRONYMS}

\begin{tabular}{|c|c|}
\hline AFV & Alternative Fuel Vehicle \\
\hline AMWTP & Advanced Mixed Waste Treatment Project \\
\hline ARRA & American Recovery and Reinvestment Act of 2009 \\
\hline ATR & Advanced Test Reactor (entire area is now called the ATR Complex) \\
\hline B20 & Biodiesel 20 (alternative fuel that is $20 \%$ biodiesel and $80 \%$ conventional diesel) \\
\hline Btu & British thermal unit \\
\hline BEA & Battelle Energy Alliance \\
\hline BPA & Bonneville Power Administration \\
\hline DOE-ID & U.S. Department of Energy Idaho Operations Office \\
\hline CEDR & Consolidated Energy Data Report \\
\hline CFA & Central Facilities Area \\
\hline CITRC & Critical Infrastructure Test Research Complex \\
\hline CNG & Compressed Natural Gas \\
\hline E85 & Ethanol 85 (alternative fuel that is $85 \%$ ethanol and $15 \%$ gasoline) \\
\hline ECM & Energy Conservation Measure \\
\hline EMS4 & Energy Management System 4 (FEMP energy data collection system) \\
\hline EROB & Engineering Research Office Building \\
\hline ESCo & Energy Services Contractor \\
\hline ESPC & Energy Savings Performance Contract \\
\hline FEC & Federal Electronics Challenge \\
\hline FEMP & Federal Energy Management Program \\
\hline FIMS & Facilities Information Management System \\
\hline GSA & General Services Administration \\
\hline ICP & Idaho Cleanup Project \\
\hline INL & Idaho National Laboratory \\
\hline INTEC & Idaho Nuclear Technology and Engineering Center \\
\hline IORC & Information Operations \& Research Center \\
\hline IRC & INL Research Center \\
\hline LEED $^{\mathrm{TM}}$ & Leadership in Energy \& Environmental Design (green building design certification) \\
\hline LNG & Liquefied Natural Gas \\
\hline MFC & Materials and Fuels Complex \\
\hline NREL & National Renewable Energy Laboratory \\
\hline NRF & Naval Reactor Facility \\
\hline REC & Renewable Energy Credit \\
\hline TEAM & Transformational Energy Action Management (TEAM) Initiative \\
\hline UESC & Utility Energy Services Contract \\
\hline
\end{tabular}


(This Page Intentionally Left Blank) 


\section{INTRODUCTION}

Executive Order 13423 "Strengthening Federal Environmental, Energy, and Transportation

Management" establishes requirements to cost effectively meet or exceed the goals and objectives of the Energy Policy Act of 2005 for energy efficiency, use of renewable energy, transportation energy, and water conservation at Federal facilities. DOE Order 430.2B "Departmental Energy, Utilities, and Transportation Management" contains requirements that the Department of Energy will accomplish to implement Executive Order 13423. The DOE Idaho Operations Office identifies and communicates specific performance objectives and targets to the INL Site contractors via performance agreements and/or other contractual direction.

DOE Order 430.2B defines an Executable Plan as an action plan setting forth a binding obligation of the applicable Site that commits appropriate personnel resources, establishes a financing plan that prioritizes the use of life-cycle cost effective private sector financing and optimizes the application of appropriations and budgeted funds, and establishes a time line for execution coupled with specific performance measures and deliverables designed to achieve the listed requirements set forth in Section 1(b).

The "INL Site Executable Plan for Energy and Transportation Fuels Management with the Annual Report", hereafter referred to as the Plan, has been developed according to the narrative requirements and suggestions from the "Guidance for FY 2009 Reporting of: DOE Order 430.2B Executable Plan Update and the Annual Report on Energy Management" issued on 6, August 2009. This Plan contains strategies and activities that will lead to continual energy, water, and transportation fuels efficiency to move the INL Site toward meeting the goals and requirements of Executive Order 13423, DOE Order 430.2B, and DOE 450.1A before the end of FY 2015. The Plan includes references to DOE/ID-10333, "INL Site Pollution Prevention Plan" to address the procurement and environmental aspects of the Orders. The Plan also summarizes energy and fuel use reporting requirements and references criteria for performing sustainable design. Energy and transportation fuels management requirements are integrated into each of the INL Site contractor's Integrated Safety Management Systems (ISMS) and Environmental Management Systems (EMS). The Energy and Transportation Fuels Management Programs are also integrated with the Ten Year Site Plan (TYSP) and operations and acquisition systems.

This DOE-ID INL Site document serves as an overall INL Site energy and transportation fuels management Executable Plan. It is supplemented by individual contractor energy and transportation fuels management plans as needed. Updates to this plan are anticipated annually with added specificity as projects are developed and requirements change. This Plan encompasses all contractors and activities at the INL Site under the control of the DOE-ID Operations Office. The operations and activities of the Naval Reactors Facility (NRF), located on the INL Site, are specifically excluded from this Plan. The Annual Report data for FY 2009 are provided on the Consolidated Energy Data Report (CEDR) that is included as Appendix B.

DOE-ID and the INL Site contractors are utilizing their existing EMS to establish goals, track, and review progress towards meeting the energy efficiency, water conservation, greenhouse gas reduction, and renewable energy goals as reflected in this plan and as flowed down in the contractor specific plans.

The INL Site, as a whole, spent nearly \$13.5 million in FY 2009 for facility and equipment energy. Of this total, $\$ 12.9$ million was spent for building energy and $\$ 600 \mathrm{k}$ was spent on equipment fuel. The managed area used over 1.05 trillion Btu's of energy and 915.3 million gallons of water. Transportation fuel use across the INL Site in FY 2009 totaled 1,119,036 gallons of various types of fuels. The fleet is composed of light duty vehicles fueled by gasoline and E85. Heavy-duty vehicles include over-the-road buses fueled by diesel, biodiesel, and LNG, and a complex assortment of trucks and equipment.

Typically, 9.5 million miles are driven annually and over 50,000 hours are logged on heavy equipment. 


\section{DOE Order 430.2B Goal Summary}

Each of the INL Site contractors is required to implement the requirements of DOE O 430.2B, specifically through the Order's Contractor Requirements Document (CRD). This Plan captures the minimum requirements of the Order and CRD.

The intent of this Plan is to provide the overall strategy for the INL Site during FY 2010. Integral to this Plan is the Annual Report including information and data for energy use and accomplishment during FY 2009.

The following graph summarizes the Annual Report data and provides an FY 2009 status of the DOE Order 430.2B goals. The FY 2009 Goals in the graph are the trend point of where the INL Site should be to remain on track to meet the overall goals by the end of FY 2015. Discussion of the FY 2009 Actual status is found in the body of this Plan and Annual Report.

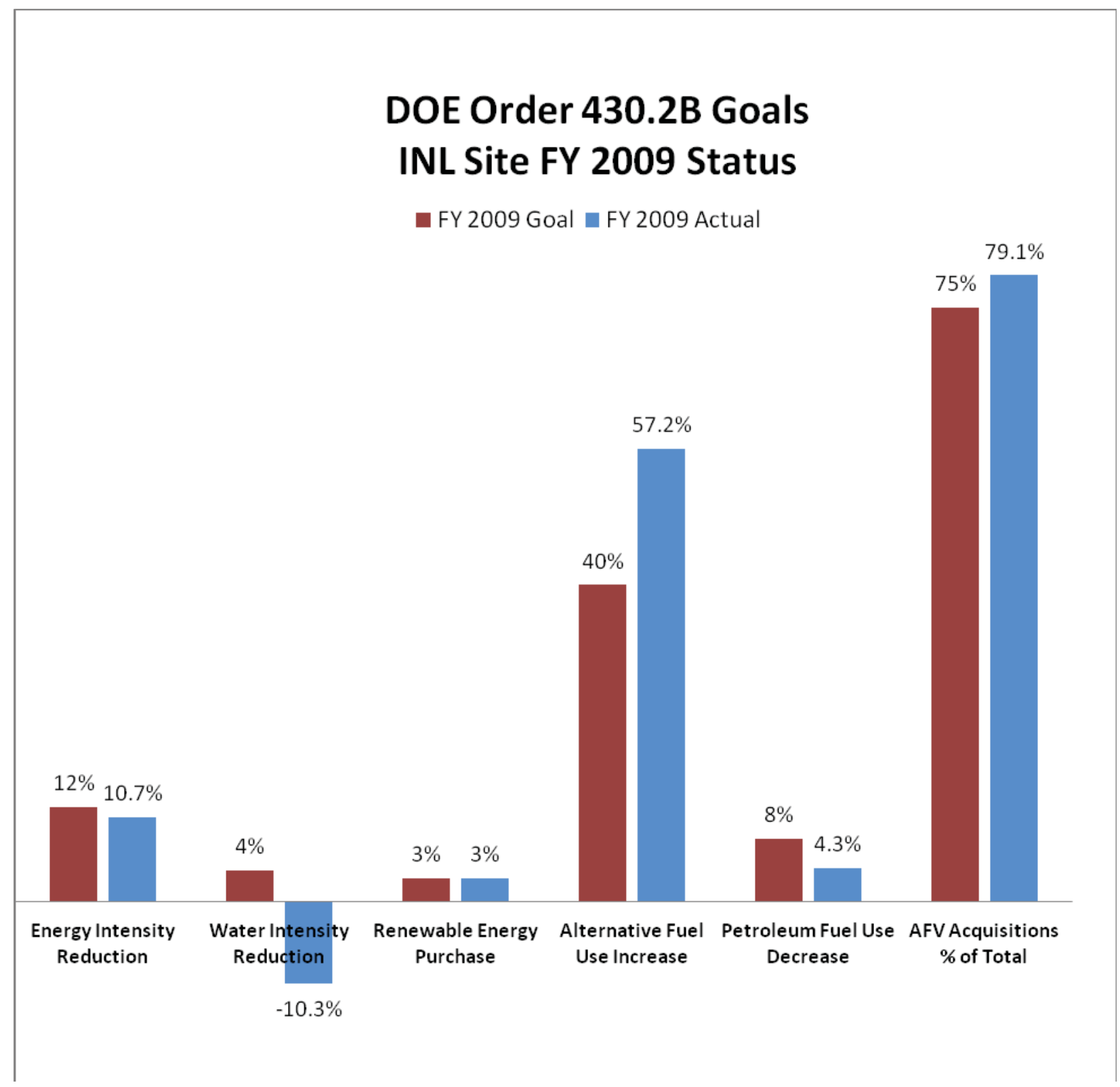


The following tables provide the overall goals and a brief discussion of the INL Site status to these goals with strategies on how the goals will be met by FY 2015.

\begin{tabular}{|c|c|}
\hline Goal & Status \& Strategy \\
\hline $\begin{array}{l}30 \% \text { energy intensity reduction } \\
\text { by FY } 2015 \text { from an FY } 2003 \\
\text { baseline } \\
\text { (Note that Energy Intensity is } \\
\text { defined as Btu/ft }{ }^{2} \text { ) }\end{array}$ & $\begin{array}{l}\text { The INL Site should be at a } 12 \% \text { reduction at the end of FY } 2009 \\
\text { and is actually at a } \mathbf{1 0 . 7 \%} \text { reduction for energy use intensity as } \\
\text { normalized for weather related factors. (Note that the CEDR } \\
\text { indicates a } 7.0 \% \text { reduction that is not normalized for weather) } \\
\text { Strategy includes implementing Energy Conservation Measures } \\
\text { primarily through the use of alternative funding mechanisms (ESPC } \\
\text { and UESC) and improving building operations. }\end{array}$ \\
\hline $\begin{array}{l}16 \% \text { water intensity reduction } \\
\text { by FY } 2015 \text { from an FY } 2007 \\
\text { Reportable Water Use baseline } \\
\text { (Note that Water Intensity is } \\
\text { defined as gallons } / \mathrm{ft}^{2} \text { ) }\end{array}$ & $\begin{array}{l}\text { The INL Site should be at a } 4 \% \text { reduction at the end of FY } 2009 \text { and } \\
\text { is actually at a } \mathbf{1 0 . 3 \%} \text { increase in water use intensity. } \\
\text { Strategy includes identifying cost effective water reduction } \\
\text { opportunities by repairing leaks and implementing operational } \\
\text { improvements primarily through the use of alternative funding } \\
\text { mechanisms. }\end{array}$ \\
\hline $\begin{array}{l}7.5 \% \text { of a site's annual } \\
\text { electricity consumption from } \\
\text { on-site renewable sources by } \\
\text { FY } 2010\end{array}$ & $\begin{array}{l}\text { The INL Site purchased a total of } 6,920 \text { MWh of Renewable Energy } \\
\text { Credits (REC) for FY 2009, which equates to a total of } 3 \% \text { of the } \\
\text { INL Site electricity usage in FY } 2008 \text {. } \\
\text { The INL Site plans to purchase RECs totaling } 16,393 \text { MWH in } \\
\text { FY 2010, which equates to } 7.5 \% \text { of the INL Site FY } 2009 \text { electricity } \\
\text { usage. }\end{array}$ \\
\hline $\begin{array}{l}\text { Every site to have at least one } \\
\text { on-site renewable energy } \\
\text { generating system }\end{array}$ & $\begin{array}{l}\text { The INL Site will continue to analyze cost effective opportunities to } \\
\text { install on-site renewable generation, however the use of RECs will } \\
\text { continue to the primary means of using Renewable Energy. }\end{array}$ \\
\hline $\begin{array}{l}10 \% \text { annual increase in fleet } \\
\text { alternative fuel consumption } \\
\text { relative to a FY } 2005 \text { baseline }\end{array}$ & $\begin{array}{l}\text { The INL Site should be at a } 40 \% \text { increase at the end of FY } 2009 \text { and } \\
\text { is actually at a } 57.2 \% \text { increase in the use of alternative fuels. } \\
\text { Strategy includes increasing the availability and use of E- } 85 \text { and } \\
\text { biodiesel, focusing on methods to increase the use of alternative } \\
\text { fuels as they become more available, determining methods to use } \\
\text { greater concentrations of biodiesel in the winter months, and } \\
\text { progressing on a FEMP identified initiative to replace the diesel } \\
\text { fueled bus fleet with compressed natural gas buses. }\end{array}$ \\
\hline $\begin{array}{l}2 \% \text { annual reduction in fleet } \\
\text { petroleum consumption } \\
\text { relative to a FY } 2005 \text { baseline }\end{array}$ & $\begin{array}{l}\text { The INL Site should be at an } 8 \% \text { reduction at the end of FY } 2009 \\
\text { and is actually at a } 4.3 \% \text { reduction in the use of petroleum based } \\
\text { fuels. } \\
\text { Strategy includes continuing to increase the use of alternative fuels } \\
\text { to assist with reducing the use of petroleum based fuels. A } \\
\text { significant opportunity for decreasing petroleum fuel while } \\
\text { increasing alternative fuel use lies in the identified project to convert } \\
\text { the bus fleet to CNG. }\end{array}$ \\
\hline
\end{tabular}




\begin{tabular}{|l|l|}
\hline \multicolumn{1}{|c|}{ Goal } & \multicolumn{1}{c|}{ Status \& Strategy } \\
\hline $\begin{array}{l}\text { 75\% of light duty vehicle } \\
\text { purchases must consist of } \\
\text { alternative fuel vehicles }\end{array}$ & $\begin{array}{l}\text { The INL Site acquires vehicles predominantly through GSA. The } \\
\text { fleet is being regularly updated with Flex-Fuel vehicles. } \\
\text { Of 273 light duty vehicles acquired in FY 2009, a total of 216 were } \\
\text { flex-fuel capable for an overall percentage of 79.1\%. }\end{array}$ \\
\hline $\begin{array}{l}\text { All new construction and major } \\
\text { renovations greater than \$5 } \\
\text { million to be LEED Gold } \\
\text { certified }\end{array}$ & $\begin{array}{l}\text { The INL Site has five new buildings in design or development at } \\
\text { the end of FY 2009 that are planned for LEED Gold certification. } \\
\text { Plans for FY 2010 include updating engineering, procurement, and } \\
\text { lease procedures and requirements to address LEED and the } \\
\text { Guiding Principles. These activities should assist with establishing } \\
\text { a permanent culture of cost effective sustainable design of new } \\
\text { facilities and major renovations. }\end{array}$ \\
\hline $\begin{array}{l}15 \% \text { of existing buildings to be } \\
\text { compliant with the five guiding } \\
\text { principles of (HPSB) design }\end{array}$ & $\begin{array}{l}\text { A total of } 18 \% \text { of the INL Site's total square footage was } \\
\text { evaluated during FY 2009 against the Guiding Principles. This } \\
\text { evaluation should lead to a significant UESC project in FY 2010. } \\
\text { ESPC and UESC funding mechanisms will be used to continue with } \\
\text { building analyses and implement applicable upgrades to achieve } \\
\text { compliancy to the 15\% HPSB design goal. }\end{array}$ \\
\hline $\begin{array}{l}\text { Advanced metering to the } \\
\text { maximum extent practicable }\end{array}$ & $\begin{array}{l}\text { The MFC ESPC is in final design and will install advanced } \\
\text { electrical meters in 28 facilities, water meters in seven facilities, } \\
\text { and steam meters in five facilities. } \\
\text { Strategy includes targeting the facilities that have been identified in } \\
\text { FIMS for meter installation candidates according to the FEMP } \\
\text { Guidance for Metering. }\end{array}$ \\
\hline
\end{tabular}

\section{Energy Intensity}

\subsection{Energy Efficiency}

To meet the energy goal in DOE 430.2B, the INL Site should be at a $12 \%$ reduction at the end of FY 2009 as compared to the established FY 2003 baseline. As demonstrated through data entered into the Consolidated Energy Data Report (CEDR) in Appendix B, the INL Site is actually at a $7.0 \%$ in energy reduction.

The INL Site normalizes energy intensity for weather related factors to provide an accurate comparison with base year FY 2003. To make this correction, the portion of energy used for space conditioning (43\% of the total as per DOE's Energy Information Administration) is adjusted to the weather conditions for the base year. In FY 2009, there were 8,684.0 Heating Degree Days as compared to only 7,892.0 in FY 2003. The end result is a corrected energy use intensity of $163,857 \mathrm{Btu} / \mathrm{ft}^{2}$ rather than $170,545 \mathrm{Btu} / \mathrm{ft}^{2}$ as provided in the CEDR. When the corrected energy use intensity is compared to $183,471 \mathrm{Btu} / \mathrm{ft}^{2}$ for FY 2003, a $10.7 \%$ reduction is calculated after normalization rather than the $7.0 \%$ as shown in the CEDR. 
Due to the nature of the various INL Site missions, many of the related operations can be cyclical and result in varying usages of energy. As facilities are removed or processes are modified, the INL Site energy usage intensity can vary seemingly unrelated to actual overall reduction efforts. As an example, in FY 2009 ARRA Stimulus funding was provided to accelerate D\&D of numerous facilities across the INL Site. This activity has contributed to an overall decrease in square footage of 32,000 square feet compared to FY 2003, which has contributed to the calculated energy intensity not being reduced as much as planned.

The INL Site made progress in FY 2009 with final design on the MFC ESPC project and finished approximately $50 \%$ of the lighting retrofit ECM. The INL Site is also developing a BPA sponsored UESC project for all Idaho Falls town facilities. The building analyses for this project development progressed through FY 2009 with project development planned for FY 2010 .

Projects that have been identified that will contribute to continued energy reductions for the INL Site include:

- Completion of the MFC ESPC project should provide an additional 5\% in energy reductions. This project is scheduled for completion by the end of FY 2011.

- The implementation cost for the Idaho Falls BPA UESC project, after all analyses have been completed, is estimated at over $\$ 3.3$ million. The analyses are expected to be completed by the end of December 2009 with final project development planned for the remainder of FY 2010.

- The Site Information Packages for an additional ESPC project have been prepared and are awaiting distribution for a solicitation of interest from the 16 Super ESPC ESCos. The areas identified for continued ESPC activities include all durable facilities at CFA, ATR-Complex, SMC, and INTEC. One or two ESPC projects should be under development in FY 2010.

- In support of potential ESPC projects, the INL Site has identified a \$1.4 million project to install electric and water metering in 68 facilities. As this project would support ESPC development, it should be funded before the next ESPC project is started and has been submitted to FEMP for potential future funding.

\subsection{Data Centers}

The INL Site has two major data centers: the Information and Operations Research Center (IORC) and the Engineering Research Office Building (EROB) Supercomputing Center. The IORC has received numerous energy efficiency upgrades over the years including lighting, insulation, roofing, HVAC and building controls. The Supercomputing Center in the EROB facility is a new data center installed in FY 2008 with several energy efficiency technologies such as efficient lighting, digital system controls, and occupancy sensors installed as part of the project.

\subsection{Building Setbacks}

All of the INL Site's major town facilities have automated building control systems and provide temperature set-back and set-up. Most of the newer buildings at the INL Site have building control systems and are programmed to provide set back and set-up control. The remainder of the older facilities range from no control to individual thermostat controls with thermostat control being prevalent. 


\section{Water Intensity}

The INL Site submitted its final 2007 Reportable Water Baseline to FEMP in February FY 2009. This baseline compiles all water pumped and used at the INL Site and credits clean water returned to the aquifer from the ATR-Complex and INTEC site areas. These two areas return State of Idaho permitted aquifer replenishment water to cold waste rapid infiltration ponds. The INL Site 2007 Reportable Water Baseline is final and is being used to determine progress with water use reductions.

To meet the water reduction goal in DOE 430.2B, the INL Site should be at a $4 \%$ reduction at the end of FY 2009 as compared to the FY 2007 Reportable Water Usage Baseline. As demonstrated through data entry into the CEDR, the INL Site is actually at a $10.3 \%$ increase in water use intensity even as the total water pumped at the INL Site has decreased from 1,060.8 MGal in FY 2007 to 915.3 MGal in FY 2009.

Water use reductions were due primarily to process changes instituted at INTEC during FY 2008 and 2009 that resulted in a decrease of 196 million gallons per year. These changes included the identification and repair of distribution system leakage that resulted in a 75 gpm reduction, and replacement of radiological flow monitoring systems that resulted in a 300 gpm reduction.

Other projects that will continue to contribute to water use reductions for the INL Site include several on-going tasks:

- In FY 2008, the New York Leak Detection, Inc. (NYLD) concluded a survey of water leaks at the INL Site and delivered a report that identified 10 leaks estimated to be leaking 12.0 million gallons per year at an annual cost of $\$ 10,274$. Due to the low cost of water, the estimated cost of $\$ 433,897$ would not result in an acceptable payback for an ESPC project, so this Measure has been submitted to FEMP for possible future funding.

- ICP will complete the ongoing INTEC water booster pump down-sizing replacement project in FY 2010 and will complete the deactivation, decommissioning and demolition of the INTEC Analytical Laboratory facilities, which will provide a combined additional 150 million gallons of annual water savings.

- INL will continue with implementation of the MFC ESPC project during FY 2010, which when complete, will provide 3.5 million gallons of annual water savings.

Due to the nature of the various INL Site missions, many of the operations can be cyclical and result in varying usages of water throughout the year and from year to year. In addition, as facilities are removed and processes are shut down, the lower square footage can actually result in an increase in water use intensity even as overall water usage is reduced. As an example, in FY 2009, the overall water pumped at the INL Site was reduced by $145.5 \mathrm{MGal}$ as compared to FY 2007, but the square footage was also reduced by $171,000 \mathrm{ft}^{2}$ due to ongoing $\mathrm{D} \& \mathrm{D}$ work, and the water returned to the aquifer at INTEC was reduced due to process changes. The end-effect was an increase in reportable water use intensity of $10.3 \%$ as compared to FY 2007.

\section{Renewable Energy}

The INL Site is actively pursuing Renewable Energy Generation capability and is annually purchasing Renewable Energy Credits (RECs) in amounts as outlined in the Energy Policy Act of 2005.

- There is one small solar transpired wall at the IRC Complex Records Storage Facility. This wall preheats outside fresh air for the office area of this facility. There are two other transpired solar walls in final design for the MFC ESPC project that should be installed in FY 2010. These solar 
walls are not Renewable Energy generation, but provide renewable energy that avoids the use of conventionally generated electricity.

- The INL Site is pursuing development of a $20 \mathrm{MW}$ wind farm by preparing permitting documentation and securing funding to install a transmission line to the boundary of the MFC Area with a preference to extend the transmission line to the actual wind farm location. This project would require between $\$ 2.5 \mathrm{M}$ and $\$ 4.0 \mathrm{M}$, but would open the way for a $\$ 60 \mathrm{M}$ privately funded wind generation facility on Federal property that could be completed by the end of FY 2011.

- The INL Site is also considering a $1 \mathrm{MW}$ solar array to be installed at the Central Facilities Area (CFA). This project is only in the conceptual stage and funding opportunities are being pursued. If funded, this project could be completed during FY 2010.

- As an interim compliance activity, the INL Site has procured a total of 6,920 MWh of Renewable Energy Credits (RECs) from Sterling Planet, Inc. through a group purchase coordinated by the National Renewable Energy Laboratory (NREL) for a total of $\$ 6,920$. This purchase represents 3\% of the INL Site electric usage in FY 2008 and is the purchase for FY 2009.

Rationale as to why this goal may not be met: Due to the low cost for electricity from abundant old hydroelectric sources, the payback for RE projects is unlikely to be successful without outside funding to support such projects.

\section{6. $\quad$ Fleet}

The INL Site is a significant user of diesel fuel especially in its bus fleet. There are great opportunities to affect DOE's petroleum fuel usage by implementing fuel reduction or fuel switching activities at the INL Site.

To meet the transportation fuels goals in DOE 430.2B, the INL Site should be at an $8 \%$ reduction in petroleum based fuels and a 40\% increase in the use of alternative fuels at the end of FY 2009 as compared to an FY 2005 baseline.

In FY 2009, the INL Site used 848,640 GGE of petroleum based fuel as compared to 886,906 GGE in FY 2005 for a 4.3\% reduction. Also consumed in FY 2009 was 270,396 GGE of alternative fuel as compared to 172,049 GGE in FY 2005 for a 57.2\% increase. Activities in FY 2009 included increasing the availability of alternative fuel by converting petroleum tanks to alternative fuel tanks and by encouraging the use of alternative fuel by all users of flex fuel vehicles.

Additional projects and activities being pursued by the INL Site that will further reduce petroleum based transportation fuels and will increase the use of alternative fuels include:

- Pursue a potential project opportunity to replace the entire bus fleet with new natural gas fueled intra-city coaches and smaller hybrid mini motor coaches. This opportunity was jointly identified by NREL and INL and is being worked with FEMP to obtain funding for implementation. This project is currently being refined to capture all relevant costs and will be updated to FEMP. It is currently estimated that this project can be completed as early as the end of FY 2011 if funding and motor coaches are available, and will provide the DOE Complex with significant petroleum reductions when complete.

- Pursue a project to update the existing fueling infrastructure to provide additional alternative fuel locations and to allow for improved fuel use tracking and control. This project has been estimated at $\$ 1.2 \mathrm{M}$, could also be completed by the end of FY 2011, and would result in a significant increase in the use of alternative fuels. 
- Several Park \& Ride options are being evaluated to reduce neighborhood bus routes and further reduce bus fleet fuel usage.

- The INL Site was selected by GSA to receive three ARRA-funded Parallel Hybrid drive shuttles to replace three 24 year-old buses. The Hybrid Shuttle will reduce petroleum use through greater efficiency and will use biodiesel. Delivery will take place in FY10.

- Continue to encourage the use of E-85 in flex-fuel vehicles at the end user level. Increased alternative fueling infrastructure and revisions to mobile fueling capability and schedules will allow for the mandatory use of E-85, except when off-site fueling is necessary. E-85 is still unavailable commercially in the local area.

- Continue to support and utilize available shuttle and taxi services and transportation within and between the various INL Site facilities.

- The INL Site has developed two conceptual $\$ 1.5 \mathrm{M}$ projects to install a permanent fueling station outside of the INTEC and the RWMC perimeter fences with dispensing infrastructure inside the fences. These two projects would eliminate the need for a portable fuel truck, increase access to alternative fuels, and allow for fueling inside the two facilities. As these projects would not be conducive to an ESPC project, they have been submitted to FEMP for potential future funding.

- The INL Site has increased its fleet, construction, and operational equipment use in FY 2009 due to American Recovery and Reinvestment Act (ARRA) funded activities.

- DOE-ID and INL are collaborating with the Yellowstone-Teton Clean Energy Coalition (local area Clean Cities program) to encourage or cooperate with local fueling stations and vendors to provide alternative fueling stations in the area.

- The INL Site incorporated a Reduce Idle Campaign in its bus fleet which is saving fuel by better managing idling times. Results are positive as 1,400 gallons a month are saved by this campaign.

\section{High Performance Sustainable Buildings}

\subsection{New Construction and Major Renovations}

The INL Site is implementing High Performance Sustainable practices and design specification in new building design and construction through the following:

- Construction is nearing completion on the new Common Support Office Building and the Test Train Assembly Facility at the Advanced Test Reactor Complex (ATRComplex). These buildings have been registered with the Green Building Council for basic LEED Certification.

- The new Research and Education Laboratory (REL) and the Radiological Environmental Sciences Laboratory (RESL) are in design and are planned for LEED Gold Certification.

- Currently developing language for lease solicitation to establish a preference for LEED Gold Certified facilities. This will be a relatively simple process for new building leases, but may be more difficult when renewing existing leases.

The INL Site also constructs buildings that are very mission specific and are not readily compatible with LEED or with the Guiding Principles. One new such facility is described as follows: 
- INTEC's new Integrated Waste Treatment Unit (IWTU) is currently anticipated to have construction completed in FY 2010. This will be a large energy intensive facility with an estimated 3-year life. Due to the mission of this facility and its energy use characteristics, it is being planned for Exclusion using Part $G$ of the Excluded Buildings Self Certification. The internal process at this facility will consume most of the metered energy.

\subsection{Existing Buildings}

- The INL Site has identified 59 buildings for audits to ensure the Guiding Principles are incorporated in at least $15 \%$ of the facilities by FY 2015 . These are essentially the same buildings planned for advanced meter installations as shown in the next section, Metering. FIMS has been updated to reflect these designations. These buildings are listed on the Existing Buildings worksheet of the CEDR.

- The ESPC and UESC funding vehicles will be used as the primary means to evaluate the identified facilities and to install all cost effective ECMs that will meet the intent of the Guiding Principles.

\section{Metering}

Most of the INL Site buildings do not have meters installed. The INL Site is planning to install advanced meters on 68 buildings as identified by the DOE Electric Metering Guidance.

- Advanced metering is required to be installed by the end of FY 2012 as far as is practicable. Practicable is defined as conforming to the DOE Buildings Electric Metering Guidance, September 27, 2006, FEMP Document \#2006.100 Rev 0.

- The INL Site contractors have performed an analysis on all existing infrastructure that will still be in place by 2015 . That analysis used the Guidance to identify $\mathbf{4 8}$ buildings managed by the INL contractor, 14 buildings managed by the ICP contractor and 4 buildings managed by the AMWTP contractor that may be cost effective to meter.

- The INL Site will be using the ESPC funding vehicle to provide the funding to install the meters. However, having the meters installed before work is started on an ESPC would be preferred. The INL Site has provided a conceptual estimate for direct funding to install meters in these 68 locations. This project was estimated at $\$ 1.4 \mathrm{M}$ and would provide for metered data to help develop more accurate ESPC projects.

\section{Energy Management}

\subsection{Proposed Funding for Projects}

The primary means of funding energy and water reduction projects will be through the alternative funding programs such as ESPC and UESC. The INL Site will leverage utility incentive programs to maximum extent available.

The INL Site has also proposed several projects for FEMP direct funding that may be available for implementation with future funding as is it appropriated. These are projects that are not conducive to alternative funding due to long paybacks or technologies and equipment that support an ESPC but do not provide direct energy or water savings such as metering. These projects have been included on the Conservation Measures worksheet of the CEDR. 


\subsection{Additional DOE O 430.2B Elements to Address in FY 2010}

Strategy includes activities necessary for the success of the INL Site Energy Management and Sustainability programs. Activities include but are not limited to:

- Development of an INL Site-wide Carbon Footprint Baseline in alignment with the new Executive Order 13514.

- Active participation and representation with industry specific conference and training programs such as GovEnergy, Federal Environmental Symposium-West, and the EFCOG Energy and Infrastructure Working Group to gain and share information on best practices and sustainable programs for energy and water conservation.

- Participation with INL Site specific working groups and networking activities to provide the various INL Site contractors with a mechanism to share lessons learned and technical information.

- Compiling reports as required for INL Site energy use and program performance validation including quarterly and annual energy use reports, monthly program reports to DOE-ID, and reports as needed to the Federal Energy Management Program (FEMP) at a minimum.

The habits and actions of all INL Site employees are an integral part of the Executable Plan. No controls or engineered systems can shut off equipment when not needed as effectively as the employees themselves. There are several actions that all employees can take to significantly reduce energy waste and taxpayer dollars needed for utility costs at the INL Site.

- Ensure that all nonessential lighting, personal computers, equipment, and other systems are turned off when not needed. Diligence with these activities when leaving for the day or an extended period during the work day can truly make a difference.

- Be aware of energy efficiency and sustainable practices. Identify additional opportunities to reduce energy use and notify cognizant facility managers when you either see or suspect energy or water waste.

- Realize that real and significant energy savings requires an effort on the part of facilities personnel. Accept and work with the changes that are needed to make the facilities and facility control systems more efficient and economical.

- Reduce the use of government passenger vehicles between the on-site and in-town facilities by maximizing utilization of existing shuttle buses and taxi systems. If a government vehicle must be used, select the most fuel efficient vehicle available.

- Schedule meetings to align with bus shuttle schedules as much as possible.

- Maximize the use of alternate fuel in all government vehicles that are bi-fuel capable.

Employee awareness and education activities will accomplished through each of the contractor's web based programs. 


\section{APPENDICES}

\subsection{Appendix A - Glossary}

Alternative Fuel - A vehicle or equipment fuel that is either not petroleum based or significantly reduces the petroleum content of the fuel. Biodiesel blends such as B20 (20\% biodiesel) and Ethanol blends such as E85 (85\% Ethanol) are the more common alternative fuels. Compressed natural gas $(\mathrm{CNG})$ and liquefied natural gas $(\mathrm{LNG})$ are also recognized alternative fuels that are not a blended fuel.

Alternative Fuel Vehicle - Alternative fuel vehicles (AFV) are specially designed to run on an alternative fuel. They can be dedicated to a single alternative fuel such as LNG, or they can be dual fuel capable of operating on both alternative such as CNG or E85 and gasoline. Diesel engine vehicles that can simply be operated on a biodiesel blend are usually not considered AFVs.

Commissioning - A process of ensuring that all building systems are installed and perform interactively according to the design intent, the systems are efficient and cost effective and meet the owner's operational needs, and the installation is adequately documented and that the operators are adequately trained.

Commissioning Authority - The individual hired by, or responsible to, the building owner and is tasked with implementing the commissioning process for a new or existing building. The Commissioning Authority is typically responsible for all aspects of the commissioning process, leads and trains the commissioning team, and witnesses or verifies all system checks or inspections throughout the process. The Commissioning Authority has final jurisdiction for the entire commissioning process.

Continuous Commissioning - Continuous commissioning involves ongoing monitoring and testing of systems as part of a regular maintenance plan to ensure optimum performance and enhanced equipment longevity. Continuous commissioning can be at a system or a building level depending upon the requirements of the stakeholders.

Energy Efficiency - The ability of a building to minimize the amount of energy used for employee safety, health, and comfort. Energy efficiency also applies to the processes that are performed inside the building, which are not necessarily part of the physical structure. Energy efficiency improvements should always be measured by life cycle cost effectiveness, and not by first cost or simple payback.

ESPC - Energy Savings Performance Contracts (ESPC) are projects that are developed, engineered, performed, and funded by an outside contractor called an Energy Services Contractor (ESCo). ESPCs are paid for through the energy savings derived from the project and are intended to be a no-cost turn-key process or project. The annual payments are made to the ESCo with funds that would have been distributed to the utility. ESPCs are especially useful when capital funding is not readily available. DOE sites can take advantage of the Super ESPC program which provides pre-evaluated ESCos familiar with Federal processes.

$H V A C$ - Heating, ventilating, and/or air conditioning (cooling) systems in a building. HVAC systems include all components, controls, and distribution systems needed to deliver conditioned air to the desired point of use. 
Indoor Environment - A building's indoor environment includes many factors including the quality of the air in and supplied to the building, temperature levels and consistency throughout the building, amount of pollutants in the work space, lighting levels and quality, levels of unwanted sound, and amount of day lighting.

INL Site - All contractors and activities at the INL Site under the control of the DOE-ID Operations Office but excludes the Naval Reactors Facility (NRF).

LEED $^{\mathrm{TM}}$ Rating System - Leadership in Energy and Environmental Design (LEED) is a tool for green building design to help design teams and owners determine green project goals, identify green design strategies, measure and monitor progress, and document success. The LEED ${ }^{\mathrm{TM}}$ Rating System was developed and is administered by the U.S. Green Building Council (USGBC), which is a national non-profit organization that includes representation from all aspects of the building industry. The LEED ${ }^{\mathrm{TM}}$ Rating System is a point system of five technical categories and four levels of certification: LEED Certified, Silver, Gold, and Platinum.

Low-Cost - Low Cost modifications or repairs may be performed during the commissioning process, but are typically implemented shortly after. Low-cost opportunities typically cost less than $\$ 500$ and can be accomplished in bundled groups.

No-Cost - Adjustments or modifications that can be made during the commissioning implementation phase by in-house crafts. These on-the-spot modifications are essentially no-cost other than the time for the craft person to be available. No-cost adjustments should be maximized during the implementation phase.

Re-commissioning - Commissioning that is performed several years after a building, which was previously commissioned, has been in operation to ensure that the building and systems are meeting the original design requirements. Re-commissioning is typically used to identify and correct malfunctions in a building that occur as the building ages and to ensure continued indoor air quality, employee productivity, and energy efficiency. Re-commissioning can also be used to address changes in ownership, building use patterns, and operation and maintenance practices. A building's use and mission often change during the building's life and these changes necessitate the need for re-commissioning to ensure that the building is capable of efficiently meeting its new and/or evolving mission.

Retro-commissioning - Applying the commissioning process to a building that has never been commissioned. Retro-commissioning is sometimes referred to as "Existing Building Commissioning" and is used to compare the building's original design parameters and operational criteria with current design and operational requirements. Retro-commissioning determines if the building is capable of meeting its current mission needs and identifies modifications required to meet those needs. Retro-commissioning then identifies upgrades to the building that will enhance its energy efficiency, tenant comfort and productivity, and indoor air quality. Retro-commissioning as a best Practice means using a whole building approach to ensure that the building is operating within well-defined criteria established by the building stakeholders.

Sustainability - The ability of a society to operate indefinitely into the future without depleting its resources. Sustainability includes concepts of green building design and construction, reuse and recycling of materials, reduced use of material and energy resources for building construction and operation, water conservation, and responsible stewardship of the environment adjacent to the building. 


\subsection{Appendix B - Consolidated Energy Data Report (CEDR)}

The FY 2009 Consolidated Energy Data Report is attached as a hard copy and/or Excel file (FY2009 Consolidated Energy Data Report.xls). 